\title{
Motor Axon Pathfinding
}

\author{
Dario Bonanomi and Samuel L. Pfaff \\ Howard Hughes Medical Institute and Gene Expression Laboratory, The Salk Institute for Biological Studies, \\ La Jolla, California 92037 \\ Correspondence: Pfaff@salk.edu
}

\begin{abstract}
Motor neurons are functionally related, but represent a diverse collection of cells that show strict preferences for specific axon pathways during embryonic development. In this article, we describe the ligands and receptors that guide motor axons as they extend toward their peripheral muscle targets. Motor neurons share similar guidance molecules with many other neuronal types, thus one challenge in the field of axon guidance has been to understand how the vast complexity of brain connections can be established with a relatively small number of factors. In the context of motor guidance, we highlight some of the temporal and spatial mechanisms used to optimize the fidelity of pathfinding and increase the functional diversity of the signaling proteins.
\end{abstract}

M otor neurons residing in the brain stem and spinal cord extend axons into the periphery and are the final relay cells for locomotor commands. These cells are among the longest projection neurons in the body and their axons follow stereotypical pathways during embryogenesis to synapse with muscle and sympathetic/parasympathetic targets. Cellular studies of motor axon navigation in developing chick and zebrafish embryos have shown that motor neurons located at different rostrocaudal positions show specific preferences for axonal pathways (see Landmesser 2001; Lewis and Eisen 2003 for reviews). This early cellular research laid the foundation for molecular studies of motor axon guidance by establishing the concept that motor neurons are in fact a diverse cell population. The molecular studies covered in this article have sought to identify genetic differences between motor neurons and to characterize the signaling pathways that underlie the specificity of motor axon targeting.

\section{DEVELOPMENT OF MOTOR NEURON DIVERSITY: TRANSCRIPTION FACTORS}

During embryonic development, a mapping relationship emerges that links the position of motor neuron cell bodies within the spinal cord to the location of their synaptic targets in the periphery. Motor neuron subtypes that extend axons together along major nerve pathways to limbs, for example, coalesce into longitudinally aligned columns in the spinal cord (Fig. 1A). Depending on the spinal cord level, each motor column is comprised of multiple motor pools, representing cells that innervate the same target, such as the pectoralis muscle

Editors: Marc Tessier-Lavigne and Alex L. Kolodkin

Additional Perspectives on Neuronal Guidance available at www.cshperspectives.org

Copyright (C) 2010 Cold Spring Harbor Laboratory Press; all rights reserved; doi: 10.1101/cshperspect.a001735

Cite this article as Cold Spring Harb Perspect Biol 2010;2:a001735 
D. Bonanomi and S.L. Pfaff
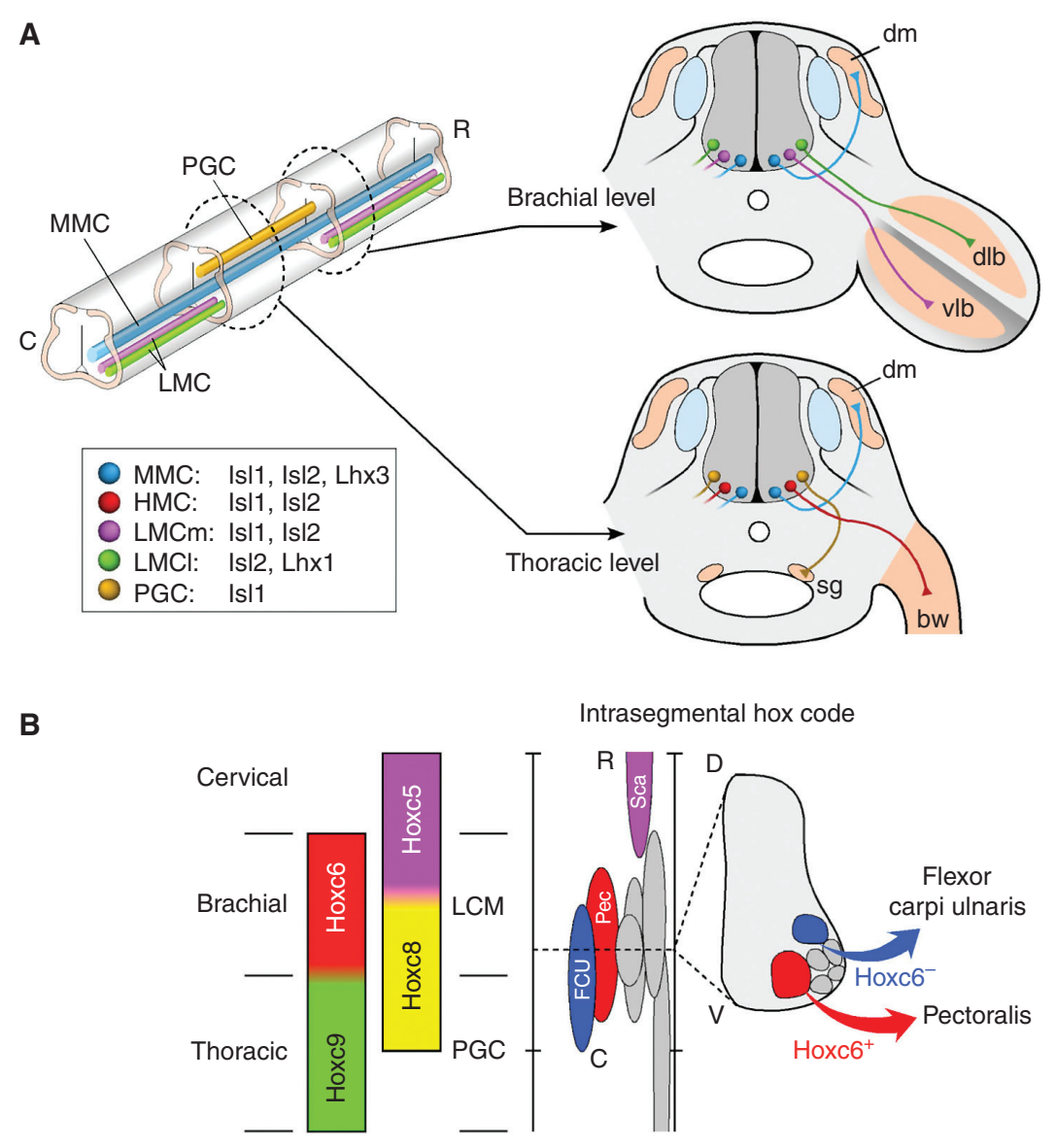

Figure 1. Motor neuron subtype diversification. (A) Motor neurons are arranged into longitudinal columns along the rostrocaudal and dorsoventral axes of the spinal cord. Motor neurons that send axons together through proximal pathways share the same columnar organization. A continuous medial motor column (MMC) spanning all rostrocaudal levels contains motor neurons projecting to the axial muscles (dm, dermomyotome). Hypaxial motor column (HMC) neurons, which innervate body wall muscles (bw), and preganglionic motor column (PGC; termed column of Terni in chick) neurons, which innervate sympathetic ganglia (sg), occupy more lateral positions exclusively at thoracic levels. The lateral motor column (LMC) spanning brachial and lumbar spinal cord levels contains limb-innervating motor neurons and is further partitioned into lateral $(\mathrm{LMCl})$ and medial $(\mathrm{LMCm})$ divisions, which segregate neurons innervating muscles of the dorsal ( $\mathrm{dlb}$ ) and ventral (vlb) limb bud, respectively. A LIM-HD code imposes columnar motor neuron identities, whereas an intrasegmental HOX code ensures that neurons innervating the same muscle group segregate in discrete motor pools $(B)$. Motor pools are variable in size, positioned at stereotypical locations, and are extensively overlapping along the rostrocaudal (R-C) and dorsoventral (D-V) axes of the neural tube. Cross-repressive interactions between rostral Hox6 activities and caudal Hox9 activities consolidate LMC and PGC columnar identities, respectively. Within the Hoxc6 domain, reciprocally exclusive activities of Hoxc5 and Hoxc8 determine the rostrocaudal position of motor pools innervating the scapulohumeralis anterior (Sca, purple), pectoralis (Pec, red), and flexor carpi ulnaris (FCU, blue) muscles. The intrasegmental segregation of FCU and Pec cells in the Hox8+ domain depends on the status of Hoxc6 in combination with other transcription factors (See text for details). 
(Fig. 1B). The rostrocadual, mediolateral, and dorsoventral positions of the cell bodies comprising each motor column and pool are conserved within a species and typically serve as the basis for naming spinal motor neuron subtypes (see Fig. 1 for details). At present, it remains unclear why motor neuron cell bodies assume such an organized pattern within the spinal cord, although it is assumed this cellular organization is somehow associated with the process of establishing proper inputs onto each motor neuron class to control complex locomotor behaviors.

Motor neuron identity is assigned through the stepwise activity of transcription factors whose expression is tuned to specific concentrations of inductive factors such as Sonic Hedgehog, Retinoic Acid, Fibroblast Growth Factors, and Wnt4/5 (Agalliu et al. 2009; for a review see Jessell 2000; Lee and Pfaff 2001). These signals trigger the expression of homeodomain (HD) transcription factors, leading to the formation of five genetically distinct progenitor cell domains marked by unique combinations of HD proteins. Within the spinal cord, all motor neurons appear to arise from the $\mathrm{pMN}$ domain marked by Pax6, Nkx6.1/6.2, and Olig2 (reviewed in Jessell 2000; Lee and Pfaff 2001). Newly generated motor neurons derived from the spinal cord pMN domain extend axons from the neural tube by taking a ventrallateral trajectory, leading to the formation of ventral spinal roots. Interestingly, at hindbrain levels, motor neurons arise from two adjacent, but genetically distinct, progenitor domainsmotor neurons extending axons out ventral roots such as cranial nerve XII are born from progenitors expressing Pax6, Nkx6.1/6.2, and Olig2 (like spinal motor neurons), whereas motor neurons exiting the neural tube from dorsal exit points arise from a more ventral progenitor cell domain that is labeled by Nkx2.2/2.9 and Nkx6.1/6.2 (Ericson et al. 1997). This distinction in dorsal-exiting and ventral-exiting motor neurons may be a carryover from the way these cells evolved, because dorsal exiting motor neurons are found in primitive chordates like Amphioxus, and ventral-exiting motor neurons seem to be a more recent addition to vertebrates coinciding with the appearance of different types of muscles for locomotion (Fritzsch and Northcutt 1993).

An abrupt switch in the complement of transcription factors occurs within cells as they transition from dividing progenitors to postmitotic motor neurons and initiate the process of axonogenesis. Two families of transcription factors have been implicated in the control of motor axon navigation: the 12 member LIM-HD class of transcription factors and the 39 member HOX family of HD proteins (Tsuchida et al. 1994; Dasen et al. 2005). Although direct target genes for these transcription factors are just beginning to be identified, genetic loss- and gain-of-function studies have established that these protein families function in a combinatorial manner to drive the diversification of motor neuron subtype identity, including regulating axonal growth. The specification of motor axon targeting by the LIM-HD and HOX transcription factors does not appear to be controlled by a static "code" that endows motor neurons with the ability to navigate the entire route to their targets; rather, the profile of transcription factors changes in many classes of motor neurons as they reach different axon choice points (Shirasaki and Pfaff 2002; Song and Pfaff 2005). Thus, two layers of gene regulation appear to control motor axon targeting-one for distinguishing individual motor neuron subtypes at the level of columns and pools (Fig. 1) and another layer of regulation that dynamically changes to coincide with the sequential choices that motor axons make as they encounter successive choice points.

One of the first examples of dynamic gene regulation during motor axonogenesis was linked to the way motor axons exit the neural tube. Motor neurons that extend axons ventrally transiently express a LIM-HD transcription factor code comprised of Isl1/2 and Lhx3/4, whereas neurons that exit dorsally lack Lhx3/4 during this initial phase of their axon growth (Sharma et al. 1998). Mice deficient in both Lhx3 and Lhx4 generate normal numbers of motor neurons, but ventral-exiting cells grow out of the neural tube from more dorsal sites. 
Despite the critical role of these redundant LIM-HD factors in axon targeting, the expression of $\mathrm{Lhx} 3 / 4$ in most ventral-exiting motor neuron subtypes is remarkably short lived.

The reorganization of the combinatorial patterns of LIM-HD transcription factors coincides with the next phase in axon navigation whereby neurons within motor columns select major peripheral nerve pathways: MMC cells grow to axial targets, HMC to body wall musculature, PCC to sympathetic ganglia, and LMC to the limb (Fig. 1A). Genetic studies have provided strong evidence that the LIM-HD factors control motor column axon choices in the periphery of the embryo. First, the down-regulation of Lhx3/4 seems to be critical for generating distinct motor columns. Only MMC neurons retain Lhx $3 / 4$ expression once axons emerge from the neural tube, whereas the other classes (HMC, PGC, and LMC) extinguish the expression quickly (Fig. 1A). The down-regulation of Lhx3 appears to be critical, because knockin mice engineered to retain $\operatorname{Lhx} 3$ in HMC, PGC, and LMC cells result in a redirection of their axons toward the axial target of the Lhx3+ MMC cells (Sharma et al. 2000). In the lateral portion of the LMC, the downregulation of $\operatorname{Lhx} 3$ is accompanied by the extinction of Isl1 and coactivation of Isl2 and Lim1 (Lhx1), which controls the proper growth of lateral-LMC axons into the dorsal limb (Kania et al. 2000).

Although direct binding of LIM-HD factors to the promoters of axon guidance receptors has yet to be established, Lhx3 has been linked to the control of fibroblast growth factor (FGF) receptor 1 (FgfR1) in MMC neurons (Shirasaki et al. 2006), Lim 1 to EphA4 in lateral-LMC cells (Kania and Jessell 2003), and Isl1 to EphB1 in medial-LMC neurons (Luria et al. 2008). The role of FgfR1, EphA4, and EphB1 in motor axon guidance is described in more detail below. Taken together, these data indicate that LIM-HD transcription factors (1) function in a combinatorial manner, (2) act at several phases of motor neuron development, (3) control axon targeting from the neural tube, and (4) control motor column guidance decisions in the periphery of embryos.
An additional layer of complexity comes to light through the study of regulatory networks of HOX-class transcription factors, which also act as key determinants of motor neuron specification and pathfinding (Dasen et al. 2005). Discrete rostrocaudal domains of HOX factors have been found to coincide with motor columns as well as the finer divisions of columns that correspond to motor pools (Fig. 1B). Hox6 paralogs are expressed by brachial LMC cells, Hox 9 paralogs by PGC cells, and Hox10 paralogs by lumbar LMC neurons. Altering the pattern of HOX expression changes the rostrocaudal identity of motor neurons, leading to corresponding alterations in their nerve-muscle connectivity (Liu et al. 2001; Dasen et al. 2003; Shah et al. 2004; Dasen et al. 2005; Dasen et al. 2008; Wu et al. 2008). Because of crossrepressive interactions between rostral Hox6 activities and caudal Hox 9 activities to establish the LMC and PGC columnar identities, the forced expression of Hoxc9 in Hoxc6 + brachial motor neurons causes the cells to inappropriately innervate the PGC target - the sympathetic ganglia (Dasen et al. 2003). Although both LIM-HD and HOX genes have been linked to the control of motor column identity, it remains unclear just how these two families of transcription factors operate in the context of one another. In one known case, the promoter of the $H b 9$ gene expressed by HMC, LMC, and MMC cells appears to be a direct target of LIM-HD and HOX factors (Lee et al. 2004; Nakano et al. 2005). Nevertheless, further work is needed to understand whether these transcription factors have epistatic relationships, synergize with one another, and/or interact to form higher-order regulatory complexes to regulate motor column axon pathfinding.

Functional studies of the HOX network have also linked these factors to the control of motor pool identity (Fig. 1B). As an example of the molecular logic governing motor pool identity, in the domain of Hoxc6 activity within the brachial spinal cord, the reciprocally exclusive expression patterns of Hoxc5 and Hoxc8 segregate motor neurons into pools for the scapulohumeralis anterior (Sca) muscle (Hoxc5+), flexor carpi ulnaris (FCU) muscle, 
and the pectoralis (Pec) (Hoxc8+) muscle. Within the Hoxc8+ domain, the intrasegmental combinatorial activities of HOX-members, Scip, Pea3, and LIM-HD proteins serve as genetic markers that differentially label the FCU and Pec motor neurons (Dasen et al. 2005). The expression of Nkx6.1 in hindlimb motor pools appears to be under the control of HOX genes (Dasen et al. 2005; Dasen et al. 2008). Mice deficient in Nkx6.1 show defects in muscle nerve branch formation and target innervation, indicating that Nkx6.1 is an intermediary step in the control of motor neuron-muscle connectivity (De Marco Garcia and Jessell 2008). In summary, the distal pathfinding choices that motor pools make to innervate individual muscles appear to be under the control of a complex combinatorial network of transcription factors from several different gene families. As with the LIM-HD factors, the HOX genes appear to function at several stages in motor neuron development to help establish motor column and motor pool identity.

\section{MOTOR AXON GROWTH FROM THE NEURAL TUBE: THE INITIAL TRAJECTORY}

A feature that distinguishes motor neurons from all other CNS neurons is their growth of axons into the periphery. Depending on the motor neuron class, the precise exit point selection can vary but generally is divided into two categories: those cells that grow ventrally (vMN) and those that exit dorsally (dMN). Motor neurons at spinal cord levels and somatic-classes of cranial motor neurons (i.e., those that innervate striated muscles) usually extend axons peripherally via ventral exit points, although there are exceptions such as the spinal accessory nerve and the trochlear nucleus, which both grow dorsally from the neural tube. Most dorsalexiting motor neurons are found in the hindbrain and typically innervate targets that are derived from neural crest cells (classified as branchiomotor or visceromotor) (for a review, see Guthrie 2007). Embryonic dMN and vMN cells have different transcription factor profiles, suggesting they may use fundamentally different signaling pathways to extend axons from the neural tube (see previous).
An important step in understanding the guidance of motor axons from the neural tube came from the study of mice deficient in the $G$ protein-coupled receptor Cxcr4 and its cytokine ligand Cxcl12 (Lieberam et al. 2005). Cxcr4 is transiently expressed by vMN cells, whereas Cxcl12 is detected in the mesenchymal cells flanking the spinal cord and caudal hindbrain (Fig. 2A). Disruption of Cxcr4:Cxcl12 signaling causes many vMNs to project dorsally within the neural epithelium, and, at rostral spinal levels where $\mathrm{dMN}$ are located, to select dorsal exit points (Fig. 2B). It remains unclear whether Cxcl12 is acting as a classic chemoattractant or possibly modifying the activity of other signaling pathways (Chalasani et al. 2003; Chalasani et al. 2007).

Semaphorin-receptor mutants in the zebrafish Plexin A3 gene (sidetracked) also display motor axon exiting defects (Palaisa and Granato 2007), providing evidence that multiple signals guide motor axons within the spinal cord. In fact, the midline is the source of many known guidance molecules implicated in motor axon growth, including Netrins, Semaphorins, Ephrins, and Slits (Colamarino and Tessier-Lavigne 1995; Guthrie and Pini 1995; Varela-Echavarria et al. 1997; Brose et al. 1999; Zou et al. 2000), which have specific effects on $\mathrm{dMN}$ and vMN axons. Thus, the precise set point of motor axon exiting may depend on which combinations of guidance cues each motor neuron subclass is programmed to respond. Nevertheless, the finding that in Cxcr4 mutants some motor axons extend into the floor plate (Lieberam et al. 2005), which expresses multiple repellents, indicates that the midline cues alone are not sufficient to drive motor axons from the neural tube.

\section{BOUNDARY CAP CELLS AND THE CONTROL OF NUCLEAR VERSUS AXON MIGRATION}

The mechanisms that allow motor axons to pierce through the basement membrane around the neural tube are not well understood, but recent studies have begun to focus on the role of a unique subset of neural crest cells that ensure axons pass out of the neuroepithelium 


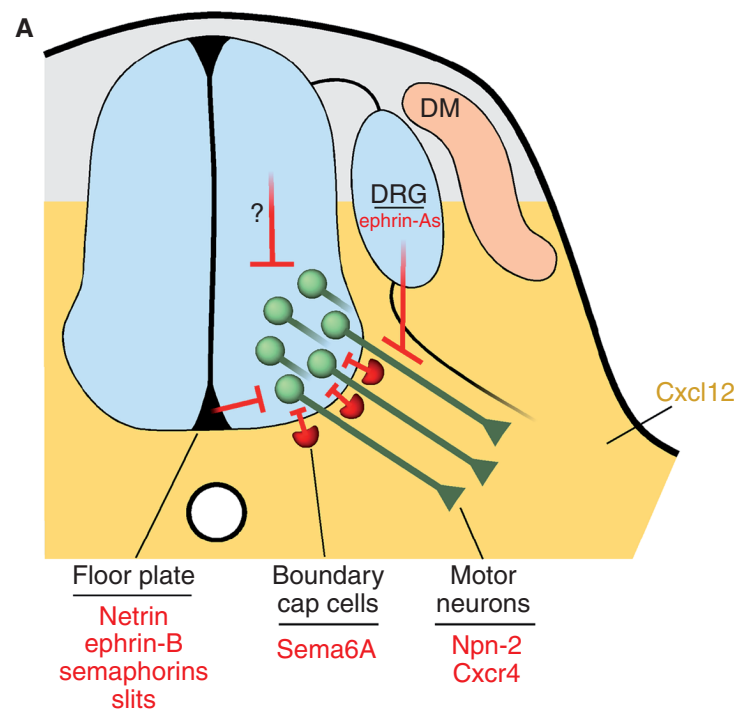

B
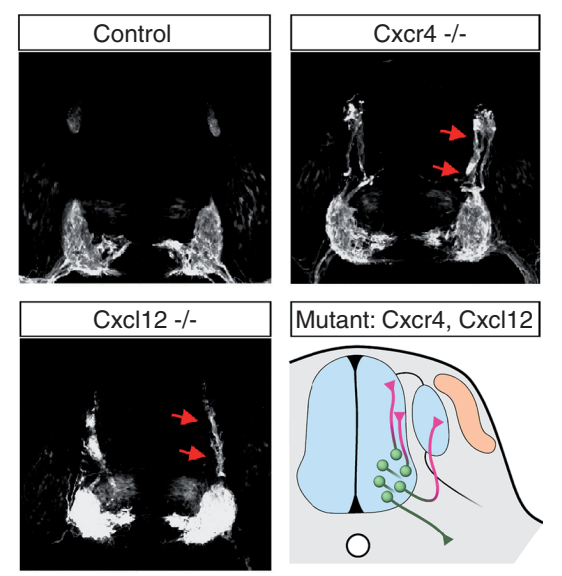

Figure 2. Motor axon outgrowth from the neural tube. (A) The initial trajectory of motor axon growth is defined by a combination of repulsive signals associated with the floor plate that orient axons away from the midline, and positive signals that attract motor axons toward their ventral exit points. Cxcl12 ligand (yellow) from the mesenchyme flanking the neural tube entices Cxrcr4-expressing motor axons to cross the neuroepithelium. It is unclear whether Cxcl12:Cxcr4 signaling has chemoattractive properties per se or influences the activity of other axon guidance systems. Sema6A expressed by boundary cap cells clustered at ventral exit points activates Nrp-2 receptors to confine motor neuron cell bodies within the neural tube. Repulsive signals from the dorsal neural tube and dorsal root ganglia (DRG) may further shape the proximal motor axon trajectory. (B) In Cxcl12 and Cxcr4 mutant embryos, motor axons marked by expression of the Hb9::gfp transgene extend dorsally within the neuroepithelium (Reprinted, with permission, from Lieberam et al. 2005). Bottom right: schematic of the motor axon phenotypes of Cxcl12 and Cxcr4 knockout embryos. Note that the aberrant axonal trajectories observed in the mutants (purple) include invasion of the DRG.

while helping to prevent motor neuron cell bodies from leaving the CNS. These neural crest cells migrate to the ventral motor exit points and dorsal sensory entry points and are called boundary cap (BC) cells (Fig. 2A). Some of the genes that have been found to mark BC cells include Krox20 (Egr2) (Wilkinson et al. 1989), TrkB (Ernfors et al. 1992), monoamine oxidase B (Vitalis et al. 2003), and cadherin 7 (Niederlander and Lumsden 1996), although rostrocaudal and species-specific differences in these markers have been noted. The ablation of $\mathrm{BC}$ cells does not perturb motor axon outgrowth per se, but does result in motor nuclei becoming ectopically located in the periphery (Vermeren et al. 2003). The defect seems to arise when motor neuron cell bodies inappropriately translocate along their axons, resulting in the unusual settling of motor nuclei in peripheral spinal nerves. BC cells appear to be the source of repulsive cues Sema6A and possibly Sema3s, and motor neurons express Neuropilin-2 (Npn-2) and Plexin-A1/A2 (Bron et al. 2007; Mauti et al. 2007) receptor complexes.

Sophisticated discrimination mechanisms must be in place to dissociate the behavior of axons from that of their cell bodies. For example, how do BC-derived semaphorins repel cell bodies but not axons? Apparently BC cells become associated with the ventral root after motor axons have extended beyond this point (Fraher et al. 2007). Convergent "desensitizing" interactions with other signaling systems might also contribute to the unresponsiveness of motor axons to BC-derived semaphorins, in spite of the expression of the appropriate receptors. In this context, it is noteworthy that Cxcr4:Cxcl12 signaling acting on motor axons has been shown to reduce the effect of repulsive molecules Sema3A and Slit-2. The attenuation 
of repulsion by Cxcr4:Cxcl12 signaling appears to be mediated by inactivation of Rho, a necessary downstream effector of repulsive signaling by Semaphorins, Slits, and ephrin-As (Wahl et al. 2000; Chalasani et al. 2003; Chalasani et al. 2007). Furthermore, the modulatory activity of Cxcr4:Cxcl12 signaling on other guidance systems might explain why, on arrival in the periphery, the axons of Cxcr4- and Cxcl12deficient vMNs frequently invade sensory ganglia, which appear to contain repulsive signals for spinal motor axons (e.g., ephrin-As) (Lieberam et al. 2005) (Fig. 2B).

\section{SPINAL NERVES AND SEGMENTAL PATTERNING}

The rostrocaudal segmentation of motor axons that give rise to the metameric organization of spinal nerves is imposed by the somites (Keynes and Stern 1984; Tosney 1988). After leaving the neural tube, motor axons grow preferentially through the anterior-half of the somite (Fig. 3), which is also the preferred substrate for neural crest migration. In particular, the posterior and ventromedial sclerotome appear to express contact repellents that confine the movement of spinal motor axons and neural crest cells to the rostral-half of the sclerotome (Fig. 3A). Early biochemical purification procedures led to the discovery of peanut agglutinin (PNA)-binding glycoproteins of 48 and $55 \mathrm{kDa}$, localized in the posterior half-sclerotome, which account for most of the growth cone collapse-inducing activity of somite extracts (Stern et al. 1986; Davies et al. 1990; Oakley and Tosney 1991; Krull et al. 1995). Surprisingly, the identity of the PNA-binding chemorepellent factors has not been determined yet. Over the years, several other molecules have been proposed as candidate contact-repellents associated with the posterior half-sclerotome (for a review, see
A

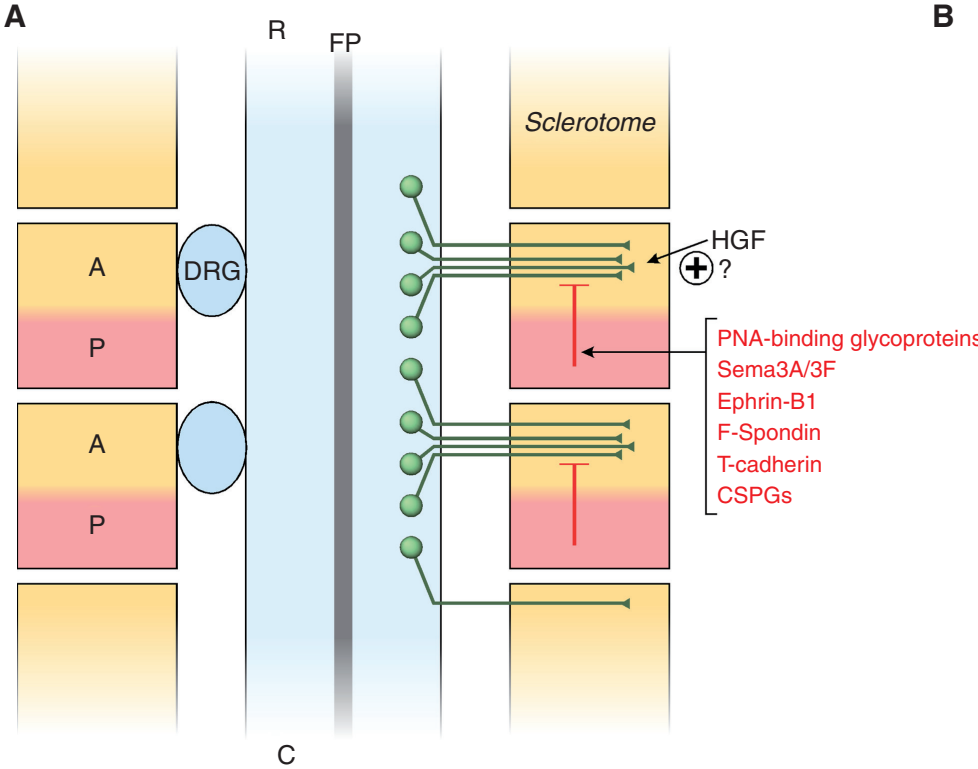

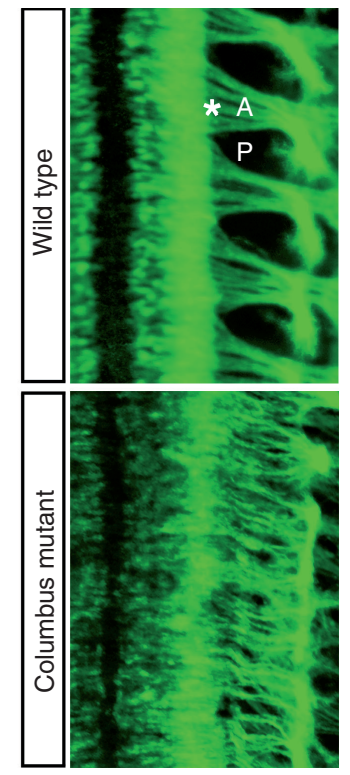

Figure 3. Origin of the metameric pattern of spinal nerves. (A) After leaving the neural tube, motor axons converge into ventral roots, which show a characteristic repetitive rostrocaudal pattern of growth through the somites. The segmentation of motor nerves is imposed by repulsive signals localized in the posterior-half $(\mathrm{P})$ of the sclerotome, thereby confining axons to the anterior somite (A) where attractive cues might be present. Neural crest cells, also sensitive to A-P somite signals, form sensory ganglia (DRG) adjacent to the anterior sclerotome. (R) rostral; (C) caudal; (FP) floor plate. (B) Top: Dorsal view of Hb9::gfp + mouse embryo shows the metameric organization of ventral roots (asterisk) extending through the anterior-half of the somites. Bottom: Aberrant motor axon segmentation in the Columbus mouse mutant isolated in a forward genetic screening (Lewcock et al. 2007): motor axons fail to converge within the anterior sclerotome. 
Kuan et al. 2004). The recent analysis of single and compound mouse mutants of the semaphorin receptors Npn-1 and Npn-2 reveals that stepwise activation of Neuropilin signaling by Sema3F and Sema3A expressed in the caudal sclerotome is required for segmental patterning of motor and sensory components. Sema3F: Npn-2 signaling guides initial motor axon outgrowth through the anterior sclerotome, whereas later Sema3A:Npn-1 signaling is required for ventral root fasciculation (Roffers-Agarwal and Gammill 2009). These findings are further supported by the observation that Npn-1 signaling controls exit point selection and restricts motor nerve branching in zebrafish (Feldner et al. 2005).

Among other candidate repulsive systems, Ephrin-B1 in the caudal-sclerotome repels motor axons expressing EphB2 receptor in vitro. Nevertheless, mouse knockouts of ephrin-B/ $E p h B$ show properly segmented spinal nerves, suggesting there are redundant signals (Orioli et al. 1996; Wang and Anderson 1997; Wang et al. 1998; Vermeren et al. 2000). The adhesion molecules F-spondin (Debby-Brafman et al. 1999; Tzarfati-Majar et al. 2001) and GPI-linked T-cadherin (Ranscht and Bronner-Fraser 1991; Fredette and Ranscht 1994; Fredette et al. 1996) are also expressed in the caudal sclerotome and have been shown to repel motor axons in vitro. Sclerotome-associated chondroitin sulphate proteoglycans (CSPGs), such as collagen IX and versican, might also play a role in segmental motor axon outgrowth (Landolt et al. 1995; Ring et al. 1995; Kubota et al. 1999; Perissinotto et al. 2000). Less is known about the role of axon attraction; however, hepatocyte growth factor (HGF) (Ebens et al. 1996) and Fgf (Shirasaki et al. 2006) are potential candidates to mediate the chemoattractive activity of the rostral sclerotomes (Hotary and Tosney 1996).

\section{PROJECTIONS TO AXIAL MUSCLES}

Shortly after entering the periphery, motor axons encounter a proximal choice point where HMC and LMC neurons select a ventral pathway to innervate body wall and limb muscles, respectively, PCG neurons make a ventral turn to reach the sympathetic ganglia, and MMC cells turn dorsally toward axial muscles (Fig. 4). Although surgical manipulation of chick embryos showed that the environment surrounding the axon trajectory rather than the final target is the main determinant of PGC pathfinding (Yip 1987; Yip 1990), a target-derived chemoattractant was proposed to guide MMC projections based on the observation that after ablation of their target, MMC axons reorient toward the next nearest dermomyotome (Tosney 1987; Tosney 1988). This hypothesis has been supported by genetic experiments whereby reprogramming HMC, LMC, and PGC motor neurons to an MMC fate by ectopic expression of the LIM-HD transcription factor Lhx3 was found to redirect their axons toward axial muscles (Sharma et al. 2000). In some cases, the reprogrammed cells took novel pathways toward the axial muscles as if they were responding to a chemoattractant (Sharma et al. 2000). This long-sought chemoattractive activity has been attributed, at least in part, to FGFs released by the dermomyotome and acting via the FgfR 1 receptor expressed by MMC cells (Shirasaki et al. 2006). Several lines of evidence suggest that FGFs are selective chemoattractants for MMC cells: (1) MMC cells are attracted toward sources of FGF4/8 when cultured in vitro, (2) ectopic-Lhx3 expression was found to trigger the expression of FgfR1 in the HMC, which correlated with the acquisition of HMC-attraction to FGF4/8, and (3) deletion of FgfR1 from mouse spinal neurons using Cre-lox genetics caused MMC axon guidance errors (Fig. 4C,D)

The penetrance of the FgfR1 mutant phenotype is incomplete (Shirasaki et al. 2006). This might be because of partial Cre-mediated recombination of the floxed-FgfR1 allele, or could reflect the contribution of additional guidance cues for directing MMC cell axons to axial muscles. Recent studies of ephrinA:EphA signaling suggest that MMC cells are repelled from inappropriate areas, such as the limb and DRG (Gallarda et al. 2008). MMC motor neurons express EphA3 and EphA4 receptors and are strongly repelled by ephrin-As in vitro. Double knockouts of EphA3 and EphA4 result in MMC misprojections into the DRG, 

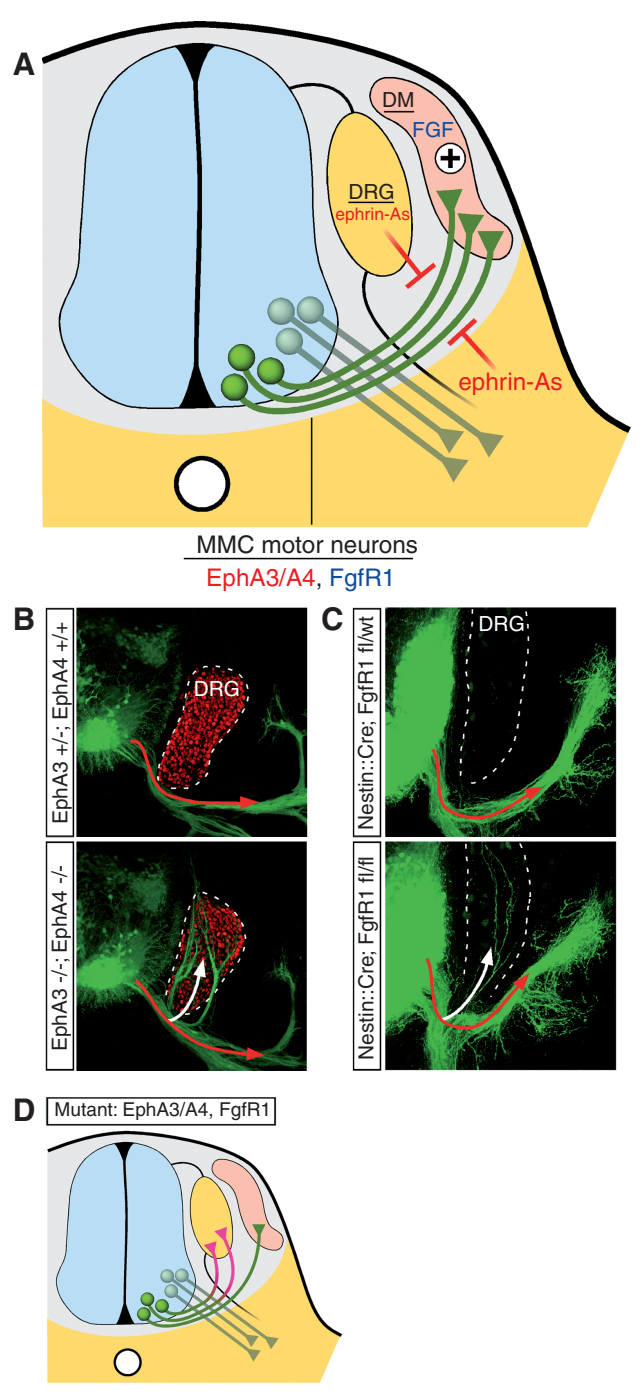

reminiscent of the phenotype observed when FgfR1 is mutated (Fig. 4B-D) (Shirasaki et al. 2006; Gallarda et al. 2008). Taken together, these findings indicate that target-derived FGFs attract MMC axons through a permissive channel between the ephrin-A repulsive environments of the DRG and flank tissue. Although FgfR1and EphA-signaling may operate independently on the actin cytoskeleton to trigger attraction and repulsion, respectively, it is also possible that they function cooperatively. Recent experiments in cell lines have unmasked physical interactions between FgfR 1 and EphA 4 and these receptors are found to potentiate each other's
Figure 4. Motor axon navigation toward the axial muscles. (A) In the immediate periphery of the neural tube, the axons of MMC neurons expressing EphA3/ A4 receptors extend though a permissive channel demarcated by repulsive ephrin-A ligands associated with the DRGs and ventral mesenchyme. FGF4/8 secreted by the demomyotome collaborate to attract FgfR1-positive MMC axons. Axons of other motor neuron subtypes do not respond to these signals and continue to extend ventrally. (B) In EphA3/ EphA4 double mutants, GFP-labeled motor axons (Tg Hb9::gfp) fail to respond to repulsive ephrin-As in the DRG and invade the sensory ganglia (white arrow), marked by Isl1 expression (red) (Reprinted, with permission, from Gallarda et al. 2008). (C) Likewise, neuron-specific ablation of FgfR 1 leads to motor axon misprojection into the DRG (white arrow) (Reprinted, with permission, from Shirasaki et al. 2006). (D) Schematic representation of the phenotypes observed in EphA3/A4 and FgfR1 mutants: MMC motor axons fail to innervate the axial muscle and aberrantly grow into the DRG (purple).

signaling (Yokote et al. 2005). Although further studies on MMC motor neurons are needed to resolve whether FgfR1 and EphA4 function as part of a hetero-signaling complex as observed in glioma cells, the two receptors appear to share downstream effectors such as ephexin1, a guanine nucleotide exchange factor (GEF) for Rhomediated axon repulsion (Shamah et al. 2001; Sahin et al. 2005; Zhang et al. 2007). Repulsive Sema3A ligands released from the DRGs might also influence the trajectory of MMC axons, helping to keep them away from the ganglia. Paradoxically, the target of MMC cells, the dermomyotome, also expresses Sema3A. Interestingly, 
the sensitivity of motor axons to Sema3A seems to be set by an autocrine pathway. MMC expression of Sema3A limits the surface availability of Npn-1 on the growth cones of these cells, thereby desensitizing them to the Sema3A produced by the surrounding tissues (Moret et al. 2007). Precise temporal regulation of this system might help to modulate motor neuron responses to semaphorins at each choice point.

\section{LMC GUIDANCE WITHIN THE LIMB}

The axons of LMC neurons ignore the proximal choice point of MMC axons and grow in tight fascicles to the base of the limb. Here, axons from multiple spinal nerves converge: at forelimb levels, segments C1-C5 join to form a cervical plexus and $\mathrm{C} 5-\mathrm{T} 1$ form the brachial plexus. At hindlimb levels, L1-L4 join to form the lumbar plexus and L4-S4 comprise the sacral plexus. Within each plexus, axons pause during development before emerging along specific nerve tracts into either the dorsal or ventral portions of the limb bud. Thus, in the plexus regions, LMC axons make key navigational choices and undergo a significant redistribution involving cell-cell contacts mediated by cell adhesion molecules L1 and NCAM. Interfering with these adhesion systems by reducing the levels of polysialic acid-modified NCAM is found to enhance motor axon fasciculation and causes projection errors (Landmesser et al. 1990; Tang et al. 1992; Tang et al. 1994).

As LMC axons emerge from the plexus region, they select either a dorsal trajectory, where most extensor muscles develop, or a ventral path toward developing flexors. This dorsoventral choice is made with great precisionmotor neurons that settle in the lateral division of the LMC ( $\mathrm{LMCl}$ ) innervate the dorsal limb, whereas medial LMC (LMCm) motor neurons grow only to the ventral limb (Landmesser 1978; Lance-Jones and Landmesser 1981a; Tosney and Landmesser 1985a; Tosney and Landmesser 1985b). Surgical rotations of the limb before innervation, or targeted gene deletions that alter dorsoventral limb patterning lead to compensatory changes in $\mathrm{LMCl}$ and $\mathrm{LMCm}$ pathfinding. Taken together, these findings suggest that cues at the base of the limb guide LMC axons (Lance-Jones and Landmesser 1981b; Ferguson 1983; Whitelaw and Hollyday 1983; Tosney and Landmesser 1984; Kania and Jessell 2003; Luria and Laufer 2007; Luria et al. 2008).

The restricted distribution of ephrin-A ligands in the ventral limb mesenchyme and EphA4 receptors in dorsally projecting $\mathrm{LMCl}$ axons provided a first clue for the involvement of the ephrin-A:EphA system in limb innervation (Fig. 5A) (Ohta et al. 1996; Eberhart et al. 2000). Misexpression experiments in chick (Eberhart et al. 2002) and knockout approaches in mouse embryos (Helmbacher et al. 2000; Kania and Jessell 2003) indicate that EphA4 mediates repulsion of $\mathrm{LMCl}$ axons from the ventral domain of ephrin-A expression through a Src family kinase-dependent pathway (Kao et al. 2009). In EphA4 mutant embryos, LMCl axons project aberrantly into the ventral half of the hindlimb, causing thinning of the peroneal nerve, the main dorsal nerve of the hindlimb (Fig. 5B,C). The expression of EphA4 in LMCl neurons requires the LIM-HD transcription factor Lim1 (Kania and Jessell 2003). Interestingly, both EphA4 and Lim1 mutants display limb innervation defects, but the phenotypes differ slightly. In EphA4 mutants, LMCl neurons grow incorrectly into the ventral limb, whereas Lim 1 mutants have randomized growth into the dorsal and ventral limb.

Because Lim1 is a transcription factor, it would not be surprising if Lim1 mutants had changes that included other guidance molecules in addition to EphA4. However, it is also possible that EphA4 has both motor neuron autonomous and nonautonomous functions, whereas Lim1 function is restricted to $\mathrm{LMCl}$ neurons. Namely, EphAs are also expressed in the dorsal limb mesenchyme where they could serve as "ligands" for ephrin-As expressed by $\mathrm{LMCl}$ axons (i.e., "reverse signaling") (Fig. 5A). Unlike the repulsive effect of EphA-mediated forward signaling, activation of ephrin-A reverse signaling promotes motor axon growth (Marquardt et al. 2005). In principle, these bidirectional interactions could occur simultaneously in individual growth cones because the coexpressed 
A
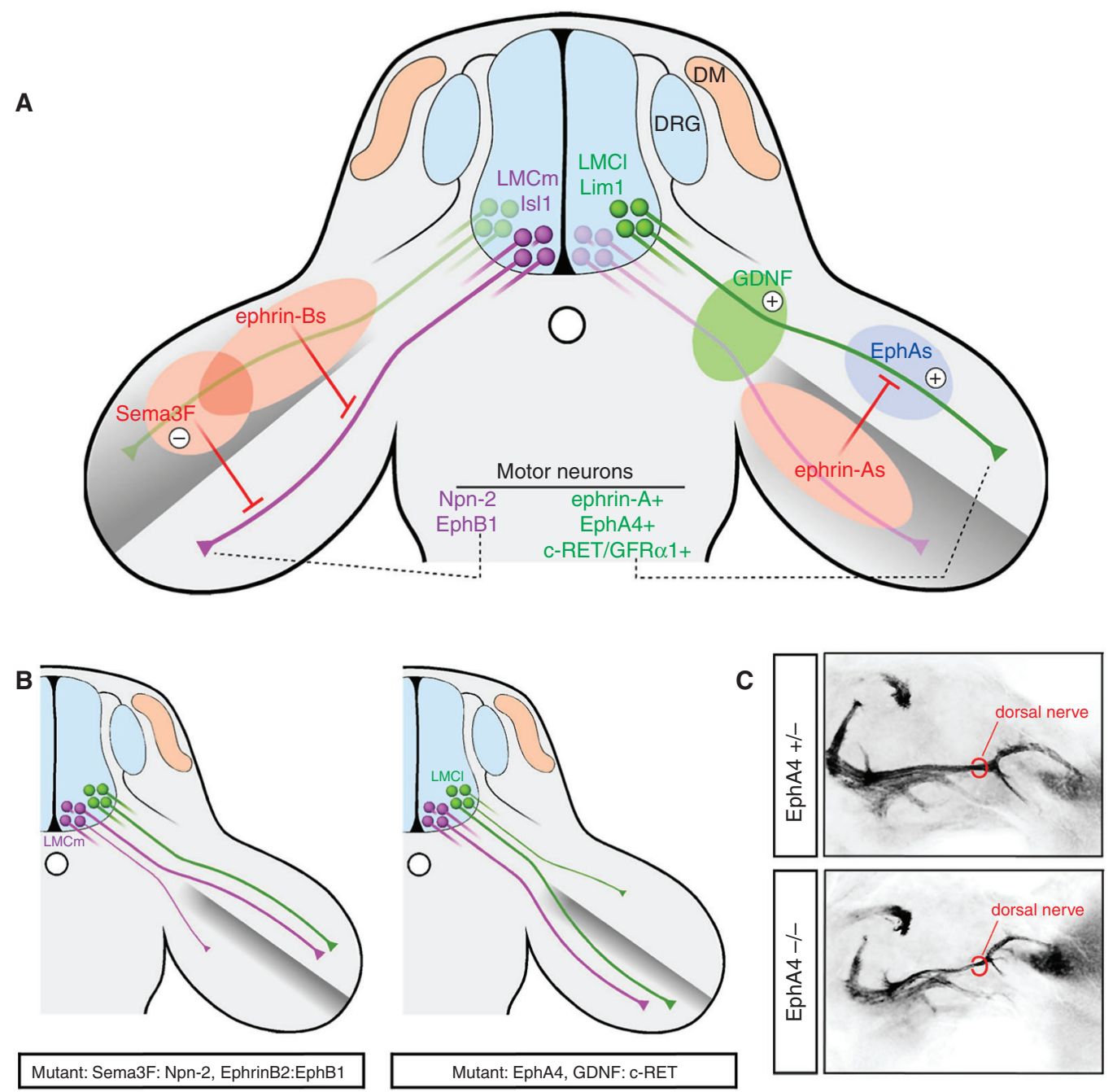

Figure 5. Motor axon navigation into the limb. (A) Left: Isl1-positive LMCm axons (purple) expressing Npn-2 and EphB1 are repelled by Sema3F and EphrinB in the dorsal limb and select a ventral trajectory. Right: A combination of repulsive and attractive signals orient Lim1-positive $\mathrm{LMCl}$ axons (green) to the dorsal limb muscles. Ephrin-As in the ventral mesenchyme trigger "forward" repulsive signaling through axonal EphA4, whereas EphAs localized in the dorsal limb may elicit attractive "reverse" signaling through axonal ephrin-As. GDNF localized at the base of the limb controls the dorsal trajectory of LMCl axons expressing c-Ret. (B) Left: Disruption of Sema3F:Npn-2 or ephrin-B:EphB1 signaling leads to dorsal projection of ventrally fated LMCm axons. Right: Ablation of EphA4 or interference with GDNF:c-Ret signaling causes dorsally projecting $\mathrm{LMCl}$ axons to select a ventral trajectory. $(C)$ Dorsal view of hindlimb innervating motor axons visualized with the Hb9::gfp transgene in e12.5 mouse embryos. The dorsal (peroneal) nerve becomes thinner in EphA4 mutants because of the misprojection of $\mathrm{LMCl}$ axons into the ventral limb (the ventral nerve is out of the plane of focus).

EphA and ephrin-A proteins localize to distinct protein islands within the neuronal membrane so that they are available to interact with ligands encountered on different cells (Marquardt et al.
2005). Thus, EphA4 null mutations might affect both forward and reverse signaling in $\mathrm{LMCl}$ neurons, whereas $\operatorname{Lim} 1$ mutants might preserve the attraction $\mathrm{LMCl}$ axons have for the dorsal 
limb from EphA-ephrin-A reverse signaling. These observations raise the intriguing possibility that EphA forward and ephrin-A reverse signaling function coordinately to determine the dorsal choice of LMCl axons. In support of this bidirectional signaling model for $\mathrm{LMCl}$ guidance, down-regulation of EphA7 in the dorsal mesenchyme of the chick wing leads to pathfinding errors of dorsally projecting motor axons (Araujo et al. 1998).

The role of ephrin-A:EphA signaling in $\mathrm{LMCl}$ neurons is paralleled by the activity of ephrin-B:EphB signaling in LMCm neurons guided to the ventral limb. LMCm cells express EphB receptors, which mediate repulsion from ephrin-B2 ligands in the dorsal limb (Fig. 5A, B) (Luria et al. 2008). Expression of EphB1, the main EphB isoform in LMCm neurons, requires the LIM-HD protein Isl1, expressed by $\mathrm{LMCm}$ but not $\mathrm{LMCl}$ neurons. In mouse embryos with limb-specific deletion of ephrin-B2 or compound mutations in EphB1/ $2 / 3$ genes, LMCm axons select an aberrant dorsal trajectory, whereas the dorsal projection of $\mathrm{LMCl}$ axons is unaffected.

Other guidance systems act in parallel or perhaps synergistically with ephrin:Eph signaling to increase the fidelity of dorsoventral navigation at the base of the limb. Genetic approaches in mouse and chick demonstrate that repulsive Sema3:Neuropilin signaling contributes to LMC axon navigation (Huber et al. 2005). Npn-2 receptor expressed by LMCm neurons mediates repulsive signaling activated by Sema3F in the dorsal limb to divert their axons ventrally (Fig. 5A, B). In contrast, the high affinity Sema3A receptor Npn-1 is expressed throughout the entire brachial LMC, and disruption of Sema3A-Npn-1 signaling impairs several aspects of limb innervation, including the timing of in-growth, axon fasciculation, and bifurcation of motor projections of both divisions of the LMC.

In addition, limb-derived growth factors such as glial cell line-derived neurotrophic factor (GDNF) and HGF play a role in motor axon navigation. GDNF is localized at the base of the limb when LMC axons are selecting their dorsoventral trajectory into the limb bud. $\mathrm{LMCl}$ axons express the GDNF receptor c-Ret, which is required for their growth into the dorsal limb (Fig. 5A, B) (Kramer et al. 2006). In mouse mutants of GDNF and $c$-Ret $\mathrm{LMCl}$ axons are misrouted to the ventral limb, similar to the phenotype displayed by EphA4 mutants (Fig. 5B). It remains to be determined whether the GDNF:c-Ret pathway provides an attractive signal for $\mathrm{LMCl}$ axons or modulates the activity of other guidance pathways involved in limb innervation. Likewise, HGF is produced by the limb mesenchyme and LMC axons express the HGF receptor c-Met as they extend toward the limb and branch to reach muscle targets (Ebens et al. 1996; Yamamoto et al. 1997). In spite of the potent chemoattractive activity of HGF in vitro, the in vivo functions of this signaling pathway are less well characterized but may contribute to muscle-specific nerve targeting (Ebens et al. 1996; Caton et al. 2000).

\section{BRANCHING OF MOTOR POOLS ON INDIVIDUAL MUSCLES}

As a result of communal responsiveness to guidance molecules imposed by motor pool-specific transcriptional programs, the axons of neurons clustered in the same pool within the spinal cord project to the same muscle with high accuracy (Landmesser 2001). Once at the muscle, individual growth cones appear to respond to specific environmental cues that ensure axons grow to the appropriate muscle subregion (Tosney and Landmesser 1985c). The observation that the rostrocaudal position of motor pools is systematically mapped onto the rostrocaudal axis of the muscles suggests that matching phenomena between complementary positional labels on motor axons and their targets ensure extensive synaptic selectivity (Laskowski and Sanes 1987; Wang et al. 1999 and references within). Remarkably, the positional information is retained in reinnervation and muscle transplantation experiments where the contribution of classic guidance phenomena can be excluded (for references, see Sanes and Lichtman 1999).

The identity of nerve-muscle recognition molecules is still largely unknown. However, 
the impaired neuromuscular topography of mouse mutants either lacking ephrin-A2/A5 or overexpressing ephrinA5 in skeletal muscles implicates the ephrin-A/EphA system in the process of nerve-muscle matching (Feng et al. 2000; Lampa et al. 2004). Work in Drosophila has begun to identify the players involved in the matching mechanisms (reviewed in Sanes 2009 and Ruiz-Canada and Budnik 2006). Leucine-rich repeat proteins, cell adhesion molecules, members of the immunoglobulin and cadherin superfamilies, as well as classic attractive and repulsive molecules such as Netrin/ DCC and semaphorins are promising candidates to be tested in vertebrates for a role in the formation of highly stereotyped nerve-muscle projection patterns.

An example of the logic that links motor pool-specific branching onto muscles and the transcriptional profiles that define pool identity is offered by the ETS-class transcription factor Pea3 (Lin et al. 1998; Arber et al. 2000). Pea3 is activated by a retrograde mechanism when motor axons encounter GDNF around the cutaneus maximus $(\mathrm{CM})$ and latissimus dorsi (LD) muscles. The induction of Pea3 by GDNF activates a motor neuron branching program, thus mice lacking GDNF display defects in CM and LD muscle innervation (Lin et al. 1998; Haase et al. 2002; Livet et al. 2002; Price et al. 2002). Interestingly, knockin mice of the GDNF receptor c-Ret harboring a point mutation in the multidocking site tyrosine-1062 have defective muscle arborization in the hindlimb, but relatively normal $\mathrm{LMCl}$ neuron pathfinding into the dorsal limb compared with $c$-Ret null mutants (see LMCl pathfinding earlier) (Gould et al. 2008). The dissociation of axon branching from axon guidance suggests that c-Ret mediates several distinct aspects of motor neuron connectivity using separate effector pathways.

At the heart of controlling growth cone turning and axon branching are signaling events that regulate cytoskeletal organization at a subcellular level. Recent studies of motor axon targeting identified the evolutionarily conserved microtubule-associated protein Phr1 in a mouse ENU screen for motor pathfinding errors (Schaefer et al. 2000; Wan et al. 2000;
DiAntonio et al. 2001; Nakata et al. 2005; Collins et al. 2006; Lewcock et al. 2007). In the absence of Phrl, motor axons grew normally and were able to respond to guidance cues in vitro. Nevertheless, embryos lacking Phrl display numerous pathfinding errors. The basis for the axon guidance phenotypes of Phrl mutants requires further investigation, but seems to be linked to microtubule destabilization and the defective morphology of growth cones. Phrl controls microtubule stability in the axon shaft by preventing the accumulation of MAP kinase activities through the degradation of DLK (dual leucine zipper kinase) (Lewcock et al., 2007). Because Phrl has been implicated in neuromuscular junction (synapse) formation and axon branching, this protein may help to coordinate axon guidance, axon branching, and synaptogenesis through a common cytoskeletal signaling pathway (Bloom et al. 2007; Lewcock et al. 2007). In addition, the recent discovery that in C.elegans the DLK-1 pathway is required for axon re-growth after lesion suggests a role for Phrl signaling in axon regeneration (Hammarlund et al. 2009; Yan et al. 2009).

\section{CONCLUDING REMARKS}

The developmental program outlined above proceeds through the stepwise acquisition of restricted transcriptional identities, which translates into progressively more specific repertoires of guidance molecules that control the stereotypical projection of each motor pool. Although this rather deterministic view may explain with good approximation the selection of the major motor axon paths, it may not entirely account for the extreme diversification and specificity observed in motor pool-muscle matching. Indeed, activity-dependent mechanisms and axon "crowding" interactions also appear to have an impact on motor axon targeting (Sharma et al. 2000; Hanson and Landmesser 2004). Particularly significant in this regard is the contribution of transaxonal signaling as a general strategy to, (1) organize pioneer-follower hierarchies between co-extending axons (Pittman et al. 
2008), (2) presort axons that establish topographic connections onto the same target (Imai et al. 2009), and (3) segregate heterotypic axons (Gallarda et al. 2008). In the motor system, axon-axon communication might explain the incomplete penetrance of the axon rerouting induced by Lhx3 overexpression, where all motor neurons are converted to the axial subclass (Sharma et al. 2000).

An emerging problem in developmental neurobiology is to explain how complex neuronal circuits can be assembled with the limited number of known guidance molecules (Dickson 2002). This is apparent in the study of motor system development, where a high degree of pathfinding diversity is generated through the repetitive use of a restricted repertoire of guidance molecules by motor neuron subtypes that project to different muscle targets. In some cases, this context-dependent use of the same signaling module seems to require sophisticated spatial and temporal regulation. For example, ephrin-A ligands in tissues flanking the neural tube divert EphA3/4-expressing MMC axons dorsally toward axial muscles, whereas LMC axons grow through this ephrin- $\mathrm{A}^{+}$ environment toward the limb (Fig. 4). On arrival at the limb, $\mathrm{LMCl}$ neurons are repelled from the ephrin- $\mathrm{A}^{+}$ventral mesenchyme (Fig. 5). Thus, the spatial/temporal regulation of ephrin-A responsiveness is a key aspect of $\mathrm{LMCl}$ pathfinding. Although the mechanistic basis for this temporal switch remains unknown, there are many possible ways EphA4 signaling might be controlled in LMCl axons. For example, EphA4 transcription may be delayed in LMC neurons relative to MMC cells. This delay might be cell-intrinsic or could be initiated by retrograde signals encountered by $\mathrm{LMCl}$ axons at the base of the limb. Alternatively, temporal regulation of EphA4 translation, insertion into the membrane, or downstream effectors like ephexin (Sahin et al. 2005) might account for the ability of LMC neurons to first ignore ephrin-A ligands proximally but acquire responsiveness distally. The well-established waiting period of LMC axons within the plexus regions at the base of the limbs might provide time for the reprogramming of LMC responsiveness to guidance cues
(Lance-Jones and Landmesser 1981a; Tosney and Landmesser 1985b; Wang and Scott 2000; Huber et al. 2005).

An additional mechanism for generating axon pathfinding diversity might derive from the use of separate signaling modules, orchestrated by distinct effectors downstream of the guidance receptors. Future studies of the pathways linking signaling at the growth cone membrane to cytoskeletal reorganization will be helpful in elucidating additional regulatory points for controlling the spatial and temporal modulation of axon growth. However, after identifying new checkpoints, it may still prove difficult to rationalize how a limited repertoire of guidance molecules is used to wire the brain. A better understanding of how growth cones integrate information from multiple guidance cues will undoubtedly be helpful in this regard.

In addition to motor axon pathfinding at the periphery, the classic guidance molecules discussed above are beginning to be implicated in the establishment of patterns of connectivity within the spinal cord. Gating of Sema6A:PlexinA4 signaling by FARP1, a Rho-GEF selectively expressed by LMC neurons, activates a subtype-specific program of dendrite arborization (Zhuang et al. 2009), which is essential for the proper assembly of sensorymotor circuits (Vrieseing and Arber 2006). Synaptic specificity is further ensured by repulsive Sema3A:PlexinD1 signaling between sensory afferents and motor neuron pools, which prevents the formation of inappropriate connections (Pecho-Vrieseling et al. 2009). Because of the well-defined neuroanatomy of motor neurons, extensive characterization of genetic markers for individual subclasses, and the emerging identification of the key receptors and ligands, studies of motor neurons will continue to serve as a useful system for understanding general principles for establishing the intricate pattern of connections within the brain.

\section{ACKNOWLEDGMENTS}

We thank members of the Pfaff lab for critical comments on the manuscript, and Joseph 
Lewcock for the images of Columbus mutant and control embryos shown in Figure 3B. This work was supported by grants to S.L.P from NINDS R37NS037116. S.L.P. is an investigator and D.B. a research associate of the Howard Hughes Medical Institute.

\section{REFERENCES}

Agalliu D, Takada S, Agalliu I, McMahon AP, Jessell TM. 2009. Motor neurons with axial muscle projections specified by Wnt4/5 signaling. Neuron 61: 708-720.

Araujo M, Piedra ME, Herrera MT, Ros MA, Nieto MA. 1998. The expression and regulation of chick EphA7 suggests roles in limb patterning and innervation. Development 125: 4195-4204.

Arber S, Ladle DR, Lin JH, Frank E, Jessell TM. 2000. ETS gene Er81 controls the formation of functional connections between group Ia sensory afferents and motor neurons. Cell 101: 485-498.

Bloom AJ, Miller BR, Sanes JR, DiAntonio A. 2007. The requirement for Phrl in CNS axon tract formation reveals the corticostriatal boundary as a choice point for cortical axons. Genes Dev 21: 2593-2606.

Bron R, Vermeren M, Kokot N, Andrews W, Little GE, Mitchell KJ, Cohen J. 2007. Boundary cap cells constrain spinal motor neuron somal migration at motor exit points by a semaphorin-plexin mechanism. Neural Dev 2: 21 .

Brose K, Bland KS, Wang KH, Arnott D, Henzel W, Goodman CS, Tessier-Lavigne M, Kidd T. 1999. Slit proteins bind Robo receptors and have an evolutionarily conserved role in repulsive axon guidance. Cell 96: 795-806.

Caton A, Hacker A, Naeem A, Livet J, Maina F, Bladt F, Klein R, Birchmeier C, Guthrie S. 2000. The branchial arches and HGF are growth-promoting and chemoattractant for cranial motor axons. Development 127: 1751-1766.

Chalasani SH, Baribaud F, Coughlan CM, Sunshine MJ, Lee VM, Doms RW, Littman DR, Raper JA. 2003. The chemokine stromal cell-derived factor-1 promotes the survival of embryonic retinal ganglion cells. J Neurosci 23: 4601-4612.

Chalasani SH, Sabol A, Xu H, Gyda MA, Rasband K, Granato M, Chien CB, Raper JA. 2007. Stromal cell-derived factor-1 antagonizes slit/robo signaling in vivo. J Neurosci 27: 973-980.

Colamarino SA, Tessier-Lavigne M. 1995. The axonal chemoattractant netrin-1 is also a chemorepellent for trochlear motor axons. Cell 81: 621-629.

Collins CA, Wairkar YP, Johnson SL, DiAntonio A. 2006. Highwire restrains synaptic growth by attenuating a MAP kinase signal. Neuron 51: 57-69.

Dasen JS, Liu JP, Jessell TM. 2003. Motor neuron columnar fate imposed by sequential phases of Hox-c activity. Nature 425: 926-933.

Dasen JS, De Camilli A, Wang B, Tucker PW, Jessell TM. 2008. Hox repertoires for motor neuron diversity and connectivity gated by a single accessory factor, FoxP1. Cell 134: 304-316.

Dasen JS, Tice BC, Brenner-Morton S, Jessell TM. 2005. A Hox regulatory network establishes motor neuron pool identity and target-muscle connectivity. Cell 123: 477-491.

Davies JA, Cook GM, Stern CD, Keynes RJ. 1990. Isolation from chick somites of a glycoprotein fraction that causes collapse of dorsal root ganglion growth cones. Neuron 4: $11-20$.

De Marco Garcia NV, Jessell TM. 2008. Early motor neuron pool identity and muscle nerve trajectory defined by postmitotic restrictions in Nkx6.1 activity. Neuron 57: 217-231.

Debby-Brafman A, Burstyn-Cohen T, Klar A, Kalcheim C. 1999. F-Spondin, expressed in somite regions avoided by neural crest cells, mediates inhibition of distinct somite domains to neural crest migration. Neuron 22: 475-488.

DiAntonio A, Haghighi AP, Portman SL, Lee JD, Amaranto AM, Goodman CS. 2001. Ubiquitination-dependent mechanisms regulate synaptic growth and function. Nature 412: 449-452.

Dickson BJ. 2002. Molecular mechanisms of axon guidance. Science 298: 1959-1964.

Ebens A, Brose K, Leonardo ED, Hanson MG Jr, Bladt F, Birchmeier C, Barres BA, Tessier-Lavigne M. 1996. Hepatocyte growth factor/scatter factor is an axonal chemoattractant and a neurotrophic factor for spinal motor neurons. Neuron 17: 1157-1172.

Eberhart J, Swartz ME, Koblar SA, Pasquale EB, Krull CE. 2002. EphA4 constitutes a population-specific guidance cue for motor neurons. Dev Biol 247: 89-101.

Eberhart J, Swartz M, Koblar SA, Pasquale EB, Tanaka H, Krull CE. 2000. Expression of EphA4, ephrin-A2 and ephrin-A5 during axon outgrowth to the hindlimb indicates potential roles in pathfinding. Dev Neurosci 22: 237-250.

Ericson J, Rashbass P, Schedl A, Brenner-Morton S, Kawakami A, van Heyningen V, Jessell TM, Briscoe J. 1997. Pax6 controls progenitor cell identity and neuronal fate in response to graded Shh signaling. Cell 90: 169-180.

Ernfors P, Merlio JP, Persson H. 1992. Cells Expressing mRNA for Neurotrophins and their Receptors During Embryonic Rat Development. Eur J Neurosci 4: $1140-1158$.

Feldner J, Becker T, Goishi K, Schweitzer J, Lee P, Schachner M, Klagsbrun M, Becker CG. 2005. Neuropilin-1a is involved in trunk motor axon outgrowth in embryonic zebrafish. Dev Dyn 234: 535-549.

Feng G, Laskowski MB, Feldheim DA, Wang H, Lewis R, Frisen J, Flanagan JG, Sanes JR. 2000. Roles for ephrins in positionally selective synaptogenesis between motor neurons and muscle fibers. Neuron 25: 295-306.

Ferguson BA. 1983. Development of motor innervation of the chick following dorsal-ventral limb bud rotations. J Neurosci 3: 1760-1772.

Fraher JP, Dockery P, O’Donoghue O, Riedewald B, O’Leary D. 2007. Initial motor axon outgrowth from the developing central nervous system. J Anat 211: 600-611. 
D. Bonanomi and S.L. Pfaff

Fredette BJ, Ranscht B. 1994. T-cadherin expression delineates specific regions of the developing motor axonhindlimb projection pathway. J Neurosci 14: 7331-7346.

Fredette BJ, Miller J, Ranscht B. 1996. Inhibition of motor axon growth by T-cadherin substrata. Development 122: 3163-3171.

Fritzsch B, Northcutt RG. 1993. Cranial and spinal nerve organization in amphioxus and lampreys: evidence for an ancestral craniate pattern. Acta Anat (Basel) 148: 96-109.

Gallarda BW, Bonanomi D, Muller D, Brown A, Alaynick WA, Andrews SE, Lemke G, Pfaff SL, Marquardt T. 2008. Segregation of axial motor and sensory pathways via heterotypic trans-axonal signaling. Science 320: 233-236.

Gould TW, Yonemura S, Oppenheim RW, Ohmori S Enomoto H. 2008. The neurotrophic effects of glial cell line-derived neurotrophic factor on spinal motoneurons are restricted to fusimotor subtypes. J Neurosci 28: 2131-2146.

Guthrie S. 2007. Patterning and axon guidance of cranial motor neurons. Nat Rev Neurosci 8: 859-871.

Guthrie S, Pini A. 1995. Chemorepulsion of developing motor axons by the floor plate. Neuron 14: 1117-1130.

Haase G, Dessaud E, Garces A, de Bovis B, Birling M, Filippi P, Schmalbruch H, Arber S, deLapeyriere O. 2002. GDNF acts through PEA3 to regulate cell body positioning and muscle innervation of specific motor neuron pools. $\mathrm{Neu}$ ron 35: 893-905.

Hammarlund M, Nix P, Hauth L, Jorgensen EM, Bastiani M. 2009. Axon regeneration requires a conserved MAP kinase pathway. Science 323: 802-806.

Hanson MG, Landmesser LT. 2004. Normal patterns of spontaneous activity are required for correct motor axon guidance and the expression of specific guidance molecules. Neuron 43: 687-701.

Helmbacher F, Schneider-Maunoury S, Topilko P, Tiret L, Charnay P. 2000. Targeting of the EphA4 tyrosine kinase receptor affects dorsal/ventral pathfinding of limb motor axons. Development 127: 3313-3324.

Hotary KB, Tosney KW. 1996. Cellular interactions that guide sensory and motor neurites identified in an embryo slice preparation. Dev Biol 176: 22-35.

Huber AB, Kania A, Tran TS, Gu C, De Marco Garcia N, Lieberam I, Johnson D, Jessell TM, Ginty DD, Kolodkin AL. 2005. Distinct roles for secreted semaphorin signaling in spinal motor axon guidance. Neuron 48: 949-964.

Imai T, Yamazaki T, Kobayakawa R, Kobayakawa K, Abe T, Suzuki M, Sakano H. 2009. Pre-target axon sorting establishes the neural map topography. Science 325: 585-590.

Jessell TM. 2000. Neuronal specification in the spinal cord: inductive signals and transcriptional codes. Nat Rev Genet 1: 20-29.

Kania A, Jessell TM. 2003. Topographic motor projections in the limb imposed by LIM homeodomain protein regulation of ephrin-A:EphA interactions. Neuron 38: 581-596.

Kania A, Johnson RL, Jessell TM. 2000. Coordinate roles for LIM homeobox genes in directing the dorsoventral trajectory of motor axons in the vertebrate limb. Cell 102: 161-173.
Kao TJ, Palmesino E, Kania A. 2009. SRC family kinases are required for limb trajectory selection by spinal motor axons. J Neurosci 29: 5690-5700.

Keynes RJ, Stern CD. 1984. Segmentation in the vertebrate nervous system. Nature 310: 786-789.

Kramer ER, Knott L, Su F, Dessaud E, Krull CE, Helmbacher F, Klein R. 2006. Cooperation between GDNF/Ret and ephrinA/EphA4 signals for motor-axon pathway selection in the limb. Neuron 50: 35-47.

Krull CE, Collazo A, Fraser SE, Bronner-Fraser M. 1995. Segmental migration of trunk neural crest: time-lapse analysis reveals a role for PNA-binding molecules. Development 121: 3733-3743.

Kuan CY, Tannahill D, Cook GM, Keynes RJ. 2004. Somite polarity and segmental patterning of the peripheral nervous system. Mech Dev 121: 1055-1068.

Kubota Y, Morita T, Kusakabe M, Sakakura T, Ito K. 1999. Spatial and temporal changes in chondroitin sulfate distribution in the sclerotome play an essential role in the formation of migration patterns of mouse neural crest cells. Dev Dyn 214: 55-65.

Lampa SJ, Potluri S, Norton AS, Fusco W, Laskowski MB. 2004. Ephrin-A5 overexpression degrades topographic specificity in the mouse gluteus maximus muscle. Brain Res Dev Brain Res 153: 271-274.

Lance-Jones C, Landmesser L. 1981a. Pathway selection by chick lumbosacral motoneurons during normal development. Proc R Soc Lond B Biol Sci 214: 1-18.

Lance-Jones C, Landmesser L. 1981b. Pathway selection by embryonic chick motoneurons in an experimentally altered environment. Proc R Soc Lond B Biol Sci 214: $19-52$.

Landmesser L. 1978. The development of motor projection patterns in the chick hind limb. J Physiol 284: 391-414.

Landmesser LT. 2001. The acquisition of motoneuron subtype identity and motor circuit formation. Int $J$ Dev Neurosci 19: 175-182.

Landmesser L, Dahm L, Tang JC, Rutishauser U. 1990. Polysialic acid as a regulator of intramuscular nerve branching during embryonic development. Neuron 4: 655-667.

Landolt RM, Vaughan L, Winterhalter KH, Zimmermann DR. 1995. Versican is selectively expressed in embryonic tissues that act as barriers to neural crest cell migration and axon outgrowth. Development 121: 2303-2312.

Laskowski MB, Sanes JR. 1987. Topographic mapping of motor pools onto skeletal muscles. J Neurosci 7: 252-260.

Lee SK, Pfaff SL. 2001. Transcriptional networks regulating neuronal identity in the developing spinal cord. Nat Neurosci 4 Suppl: 1183-1191.

Lee SK, Jurata LW, Funahashi J, Ruiz EC, Pfaff SL. 2004. Analysis of embryonic motoneuron gene regulation: derepression of general activators function in concert with enhancer factors. Development 131: 3295-3306.

Lewcock JW, Genoud N, Lettieri K, Pfaff SL. 2007. The ubiquitin ligase $\mathrm{Phr} 1$ regulates axon outgrowth through modulation of microtubule dynamics. Neuron 56: 604-620.

Lewis KE, Eisen JS. 2003. From cells to circuits: development of the zebrafish spinal cord. Prog Neurobiol 69: 419-449.

Lieberam I, Agalliu D, Nagasawa T, Ericson J, Jessell TM. 2005. A Cxcl12-CXCR4 chemokine signaling pathway 
defines the initial trajectory of mammalian motor axons. Neuron 47: 667-679.

Lin JH, Saito T, Anderson DJ, Lance-Jones C, Jessell TM, Arber S. 1998. Functionally related motor neuron pool and muscle sensory afferent subtypes defined by coordinate ETS gene expression. Cell 95: 393-407.

Liu JP, Laufer E, Jessell TM. 2001. Assigning the positional identity of spinal motor neurons: rostrocaudal patterning of Hox-c expression by FGFs, Gdf11, and retinoids. Neuron 32: 997-1012.

Livet J, Sigrist M, Stroebel S, De Paola V, Price SR, Henderson CE, Jessell TM, Arber S. 2002. ETS gene Pea3 controls the central position and terminal arborization of specific motor neuron pools. Neuron 35: 877-892.

Luria V, Laufer E. 2007. Lateral motor column axons execute a ternary trajectory choice between limb and body tissues. Neural Dev 2: 13.

Luria V, Krawchuk D, Jessell TM, Laufer E, Kania A. 2008. Specification of motor axon trajectory by ephrin-B:EphB signaling: symmetrical control of axonal patterning in the developing limb. Neuron 60: 1039-1053.

Marquardt T, Shirasaki R, Ghosh S, Andrews SE, Carter N, Hunter T, Pfaff SL. 2005. Coexpressed EphA receptors and ephrin-A ligands mediate opposing actions on growth cone navigation from distinct membrane domains. Cell 121: 127-139.

Mauti O, Domanitskaya E, Andermatt I, Sadhu R, Stoeckli ET. 2007. Semaphorin6A acts as a gate keeper between the central and the peripheral nervous system. Neural Dev 2: 28.

Moret F, Renaudot C, Bozon M, Castellani V. 2007. Semaphorin and neuropilin co-expression in motoneurons sets axon sensitivity to environmental semaphorin sources during motor axon pathfinding. Development 134: 4491-4501.

Nakano T, Windrem M, Zappavigna V, Goldman SA. 2005. Identification of a conserved 125 base-pair $\mathrm{Hb} 9$ enhancer that specifies gene expression to spinal motor neurons. Dev Biol 283: 474-485.

Nakata K, Abrams B, Grill B, Goncharov A, Huang X, Chisholm AD, Jin Y. 2005. Regulation of a DLK-1 and p38 MAP kinase pathway by the ubiquitin ligase RPM-1 is required for presynaptic development. Cell 120: $407-420$.

Niederlander C, Lumsden A. 1996. Late emigrating neural crest cells migrate specifically to the exit points of cranial branchiomotor nerves. Development 122: 2367-2374.

Oakley RA, Tosney KW. 1991. Peanut agglutinin and chondroitin-6-sulfate are molecular markers for tissues that act as barriers to axon advance in the avian embryo. Dev Biol 147: 187-206.

Ohta K, Nakamura M, Hirokawa K, Tanaka S, Iwama A, Suda T, Ando M, Tanaka H. 1996. The receptor tyrosine kinase, Cek8, is transiently expressed on subtypes of motoneurons in the spinal cord during development. Mech Dev 54: 59-69.

Orioli D, Henkemeyer M, Lemke G, Klein R, Pawson T. 1996. Sek4 and Nuk receptors cooperate in guidance of commissural axons and in palate formation. EMBO $J$ 15: 6035-6049.
Palaisa KA, Granato M. 2007. Analysis of zebrafish sidetracked mutants reveals a novel role for Plexin A3 in intraspinal motor axon guidance. Development 134: 3251-3257.

Pecho-Vrieseling E, Sigrist M, Yoshida Y, Jessell TM, Arber S. 2009. Specificity of sensory-motor connections encoded by Sema3e-Plxnd1 recognition. Nature 459: 842-846.

Perissinotto D, Iacopetti P, Bellina I, Doliana R, Colombatti A, Pettway Z, Bronner-Fraser M, Shinomura T, Kimata K, Morgelin M, et al. 2000. Avian neural crest cell migration is diversely regulated by the two major hyaluronanbinding proteoglycans PG-M/versican and aggrecan. Development 127: 2823-2842.

Pittman AJ, Law MY, Chien CB. 2008. Pathfinding in a large vertebrate axon tract: isotypic interactions guide retinotectal axons at multiple choice points. Development 135: $2865-2871$.

Price SR, De Marco Garcia NV, Ranscht B, Jessell TM. 2002. Regulation of motor neuron pool sorting by differential expression of type II cadherins. Cell 109: 205-216.

Ranscht B, Bronner-Fraser M. 1991. T-cadherin expression alternates with migrating neural crest cells in the trunk of the avian embryo. Development 111: 15-22.

Ring C, Lemmon V, Halfter W. 1995. Two chondroitin sulfate proteoglycans differentially expressed in the developing chick visual system. Dev Biol 168: 11-27.

Roffers-Agarwal J, Gammill LS. 2009. Neuropilin receptors guide distinct phases of sensory and motor neuronal segmentation. Development 136: 1879-1888.

Ruiz-Canada C, Budnik V. 2006. Introduction on the use of the Drosophila embryonic/larval neuromuscular junction as a model system to study synapse development and function, and a brief summary of pathfinding and target recognition. Int Rev Neurobiol 75: 1-31.

Sahin M, Greer PL, Lin MZ, Poucher H, Eberhart J, Schmidt S, Wright TM, Shamah SM, O'Connell S, Cowan CW, et al. 2005. Eph-dependent tyrosine phosphorylation of ephexin1 modulates growth cone collapse. Neuron 46: 191-204.

Sanes JR, Lichtman JW. 1999. Development of the vertebrate neuromuscular junction. Апnи Rev Neurosci 22: $389-442$.

Sanes JR, Yamagata M. 2009. Synaptic Specificity. Annu Rev Cell Dev Biol 25: 161-195.

Schaefer AM, Hadwiger GD, Nonet ML. 2000. rpm-1, a conserved neuronal gene that regulates targeting and synaptogenesis in C. elegans. Neuron 26: 345-356.

Shah V, Drill E, Lance-Jones C. 2004. Ectopic expression of Hoxd10 in thoracic spinal segments induces motoneurons with a lumbosacral molecular profile and axon projections to the limb. Dev Dyn 231: 43-56.

Shamah SM, Lin MZ, Goldberg JL, Estrach S, Sahin M, Hu L, Bazalakova M, Neve RL, Corfas G, Debant A, et al. 2001. EphA receptors regulate growth cone dynamics through the novel guanine nucleotide exchange factor ephexin. Cell 105: 233-244.

Sharma K, Leonard AE, Lettieri K, Pfaff SL. 2000. Genetic and epigenetic mechanisms contribute to motor neuron pathfinding. Nature 406: 515-519.

Sharma K, Sheng HZ, Lettieri K, Li H, Karavanov A, Potter S, Westphal H, Pfaff SL. 1998. LIM homeodomain factors 
Lhx3 and Lhx4 assign subtype identities for motor neurons. Cell 95: 817-828.

Shirasaki R, Pfaff SL. 2002. Transcriptional codes and the control of neuronal identity. Annu Rev Neurosci 25: 251-281.

Shirasaki R, Lewcock JW, Lettieri K, Pfaff SL. 2006. FGF as a target-derived chemoattractant for developing motor axons genetically programmed by the LIM code. Neuron 50: $841-853$.

Song MR, Pfaff SL. 2005. Hox genes: the instructors working at motor pools. Cell 123: 363-365.

Stern CD, Sisodiya SM, Keynes RJ. 1986. Interactions between neurites and somite cells: inhibition and stimulation of nerve growth in the chick embryo. J Embryol Exp Morphol 91: 209-226.

Tang J, Landmesser L, Rutishauser U. 1992. Polysialic acid influences specific pathfinding by avian motoneurons. Neuron 8: 1031-1044.

Tang J, Rutishauser U, Landmesser L. 1994. Polysialic acid regulates growth cone behavior during sorting of motor axons in the plexus region. Neuron 13: 405-414.

Tosney KW. 1987. Proximal tissues and patterned neurite outgrowth at the lumbosacral level of the chick embryo: deletion of the dermamyotome. Dev Biol 122: 540-558.

Tosney KW. 1988. Proximal tissues and patterned neurite outgrowth at the lumbosacral level of the chick embryo: partial and complete deletion of the somite. Dev Biol 127: $266-286$

Tosney KW, Landmesser LT. 1984. Pattern and specificity of axonal outgrowth following varying degrees of chick limb bud ablation. J Neurosci 4: 2518-2527.

Tosney KW, Landmesser LT. 1985a. Development of the major pathways for neurite outgrowth in the chick hindlimb. Dev Biol 109: 193-214.

Tosney KW, Landmesser LT. 1985b. Growth cone morphology and trajectory in the lumbosacral region of the chick embryo. J Neurosci 5: 2345-2358.

Tosney KW, Landmesser LT. 1985c. Specificity of early motoneuron growth cone outgrowth in the chick embryo. J Neurosci 5: 2336-2344.

Tsuchida T, Ensini M, Morton SB, Baldassare M, Edlund T, Jessell TM, Pfaff SL. 1994. Topographic organization of embryonic motor neurons defined by expression of LIM homeobox genes. Cell 79: 957-970.

Tzarfati-Majar V, Burstyn-Cohen T, Klar A. 2001. F-spondin is a contact-repellent molecule for embryonic motor neurons. Proc Natl Acad Sci 98: 4722-4727.

Varela-Echavarria A, Tucker A, Puschel AW, Guthrie S. 1997. Motor axon subpopulations respond differentially to the chemorepellents netrin-1 and semaphorin D. Neuron 18: 193-207.

Vermeren MM, Cook GM, Johnson AR, Keynes RJ, Tannahill D. 2000. Spinal nerve segmentation in the chick embryo: analysis of distinct axon-repulsive systems. Dev Biol 225: 241-252.

Vermeren M, Maro GS, Bron R, McGonnell IM, Charnay P, Topilko P, Cohen J. 2003. Integrity of developing spinal motor columns is regulated by neural crest derivatives at motor exit points. Neuron 37: 403-415.
Vitalis T, Alvarez C, Chen K, Shih JC, Gaspar P, Cases O. 2003. Developmental expression pattern of monoamine oxidases in sensory organs and neural crest derivatives. J Comp Neurol 464: 392-403.

Vrieseling E, Arber S. 2006. Target-induced transcriptional control of dendritic patterning and connectivity in motor neurons by the ETS gene Pea3. Cell 127: 1439-1452.

Wahl S, Barth H, Ciossek T, Aktories K, Mueller BK. 2000. Ephrin-A5 induces collapse of growth cones by activating Rho and Rho kinase. J Cell Biol 149: 263-270.

Wan HI, DiAntonio A, Fetter RD, Bergstrom K, Strauss R, Goodman CS. 2000. Highwire regulates synaptic growth in Drosophila. Neuron 26: 313-329.

Wang HU, Anderson DJ. 1997. Eph family transmembrane ligands can mediate repulsive guidance of trunk neural crest migration and motor axon outgrowth. Neuron 18: 383-396.

Wang G, Scott SA. 2000. The "waiting period" of sensory and motor axons in early chick hindlimb: its role in axon pathfinding and neuronal maturation. $J$ Neurosci 20: $5358-5366$.

Wang H, Chadaram SR, Norton AS, Lewis R, Boyum J, Trumble W, Sanes JR, Laskowski MB. 1999. Positionally selective growth of embryonic spinal cord neurites on muscle membranes. J Neurosci 19: 4984-4993.

Wang HU, Chen ZF, Anderson DJ. 1998. Molecular distinction and angiogenic interaction between embryonic arteries and veins revealed by ephrin-B2 and its receptor Eph-B4. Cell 93: 741-753.

Whitelaw V, Hollyday M. 1983. Neural pathway constraints in the motor innervation of the chick hindlimb following dorsoventral rotations of distal limb segments. J Neurosci 3: $1226-1233$.

Wilkinson DG, Bhatt S, Chavrier P, Bravo R, Charnay P. 1989. Segment-specific expression of a zinc-finger gene in the developing nervous system of the mouse. Nature 337: 461-464.

Wu Y, Wang G, Scott SA, Capecchi MR. 2008. Hoxc10 and Hoxd10 regulate mouse columnar, divisional and motor pool identity of lumbar motoneurons. Development 135: 171-182.

Yamamoto Y, Livet J, Pollock RA, Garces A, Arce V, deLapeyriere O, Henderson CE. 1997. Hepatocyte growth factor (HGF/SF) is a muscle-derived survival factor for a subpopulation of embryonic motoneurons. Development 124: 2903-2913.

Yan D, Wu Z, Chisholm AD, Jin Y. 2009. The DLK-1 kinase promotes mRNA stability and local translation in C. elegans synapses and axon regeneration. Cell 138: 1005-1018.

Yip JW. 1987. Target cues are not required for the guidance of sympathetic preganglionic axons. Brain Res 429: 155-159.

Yip JW. 1990. Identification of location and timing of guidance cues in sympathetic preganglionic axons of the chick. J Neurosci 10: 2476-2484.

Yokote H, Fujita K, Jing X, Sawada T, Liang S, Yao L, Yan X, Zhang Y, Schlessinger J, Sakaguchi K. 2005. Trans- 
activation of EphA4 and FGF receptors mediated by direct interactions between their cytoplasmic domains. Proc Natl Acad Sci 102: 18866-18871.

Zhang Y, Sawada T, Jing X, Yokote H, Yan X, Sakaguchi K. 2007. Regulation of ephexin1, a guanine nucleotide exchange factor of Rho family GTPases, by fibroblast growth factor receptor-mediated tyrosine phosphorylation. J Biol Chem 282: 31103-31112.
Zhuang B, Su YS, Sockanathan S. 2009. FARP1 promotes the dendritic growth of spinal motor neuron subtypes through transmembrane Semaphorin6A and PlexinA4 signaling. Neuron 61: 359-372.

Zou Y, Stoeckli E, Chen H, Tessier-Lavigne M. 2000. Squeezing axons out of the gray matter: a role for slit and semaphorin proteins from midline and ventral spinal cord. Cell 102: 363-375. 


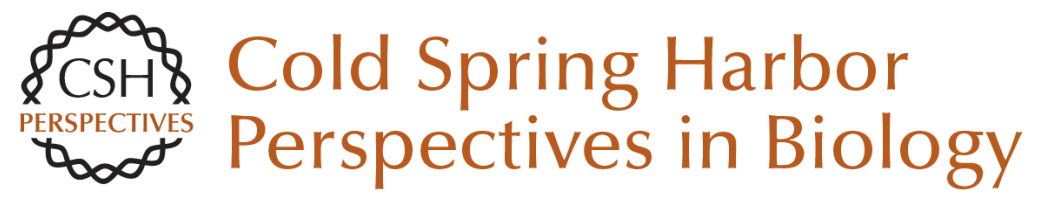

\section{Motor Axon Pathfinding}

Dario Bonanomi and Samuel L. Pfaff

Cold Spring Harb Perspect Biol 2010; doi: 10.1101/cshperspect.a001735 originally published online February 10, 2010

\section{Subject Collection Neuronal Guidance}

Mechanisms and Molecules of Neuronal Wiring: A Primer

Alex L. Kolodkin and Marc Tessier-Lavigne

Guidance Molecules in Axon Pruning and Cell

Death

Pierre Vanderhaeghen and Hwai-Jong Cheng

Initiating and Growing an Axon

F. Polleux and William Snider

Navigating Intermediate Targets: The Nervous System Midline

Barry J. Dickson and Yimin Zou

Cellular Strategies of Axonal Pathfinding

Jonathan Raper and Carol Mason

Guidance Molecules in Axon Regeneration

Roman J. Giger, Edmund R. Hollis II and Mark H. Tuszynski

Signaling from Axon Guidance Receptors Greg J. Bashaw and Rüdiger Klein

Visual Map Development: Bidirectional Signaling, Bifunctional Guidance Molecules, and Competition

David A. Feldheim and Dennis D. M. O'Leary
Wiring the Brain: The Biology of Neuronal

Guidance

Alain Chédotal and Linda J. Richards

Guidance Molecules in Synapse Formation and

Plasticity Kang Shen and Christopher W. Cowan

The Growth Cone Cytoskeleton in Axon

Outgrowth and Guidance

Erik W. Dent, Stephanie L. Gupton and Frank B. Gertler

Topographic Mapping--The Olfactory System Takeshi Imai, Hitoshi Sakano and Leslie B. Vosshall

Self-avoidance and Tiling: Mechanisms of

Dendrite and Axon Spacing Wesley B. Grueber and Alvaro Sagasti

Trafficking Guidance Receptors Bettina Winckler and Ira Mellman

Axon Guidance Molecules in Vascular Patterning Ralf H. Adams and Anne Eichmann

Human Genetic Disorders of Axon Guidance Elizabeth C. Engle

For additional articles in this collection, see http://cshperspectives.cshlp.org/cgi/collection/

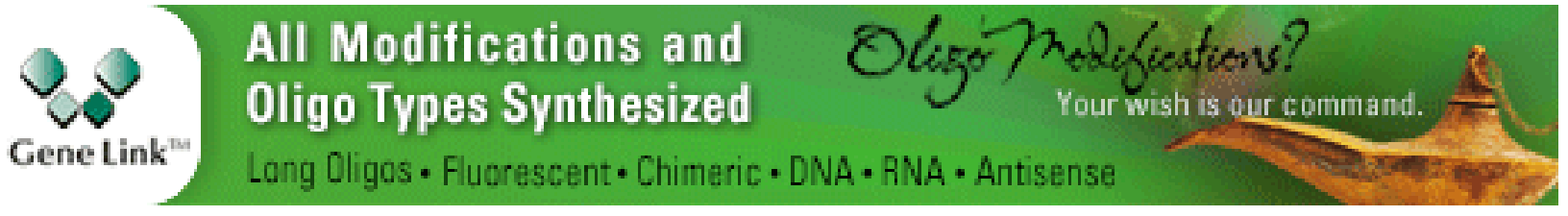

Copyright @ 2010 Cold Spring Harbor Laboratory Press; all rights reserved 